\title{
Decision Support System Selection of Best Employee At PT. Intiberkah Sinar Sejahtera Using Simple Additive weighting Method
}

\author{
Feri Sahputra ${ }^{1}$, Fricles Ariwisanto Sianturi ${ }^{2}$ \\ ${ }^{1,2}$ Informatics Engineering Study Program, STMIK Pelita Nusantara, Jl. St. Iskandar Muda \\ No. 1 Medan, Nort Sumatera, Indonesia, 20154 \\ E-mail:ferisyahputra742@gmail.com,sianturifricles@gmail.com
}

\begin{abstract}
The problem of PT. Sinar Sejahtera Intiberkah are still many employees of PT. Intiberkah Sinar Sejahtera especially the logistics employees who are critical to the company that should be worthy to obtain as the best employees but until now there has been no employees at the logistics become the best employee in the company of PT. Sinar Sejahtera Intiberkah tersebut.Oleh Therefore, in this study used a decision support system that can be used to help the PT. Intiberkah Sinar Sejahtera in determining the eligible employees in the selection of the best employees, there are four criteria taken in these elections is the first no ethical criteria, these criteria related to attitudes and ways of speaking with courtesy to superiors.
\end{abstract}

Keywords : Selection of Best Employee (PKT), Decision Support System (DSS), Simple Additive Weighting $(S A W)$.

\section{Introduction}

PT. Intiberkah Sinar Sejahtera (SIS) is a company engaged in construction services in the manufacture of building manufacturing plant. Starting from business entities formed CV and then with diligence accompanied by hard work and commitment, in 1997 the company increased to make a PT, armed with a business license and the confidence of the government of the company continues to improve the quality of work, work effectiveness and efficiency as well as improve service standards work and along with advances in technology and the demands of customers and the competition is very competitive in competitions construction services with pioneering work as executor of buildings / factories. In a period of twenty years of age, PT. Intiberkah Sinar Sejahtera has completed more than 120 projects well. The problem of PT. Sinar Sejahtera Intiberkah are still many employees of PT. Intiberkah Sinar Sejahtera especially the logistics employees who are critical to the company that should be worthy to obtain as the best employees but until now there has been no employees at the logistics become the best employee in the company of the Prosperous Intiberkah PT.Sinar. Therefore, in this study used a decision support system that can be used to help the PT. Intiberkah Sinar Sejahtera in determining the eligible employees in the selection of the best employees, there are five criteria taken in these elections is the first no ethical criteria, these criteria related to attitudes and ways of speaking with courtesy to superiors,

\section{Theory}

\subsection{Simple Additive weighting}

Simple Additive weighting method (SAW) can be interpreted as a simple weighting method or weighted summation on solving problems in a decision support system. The concept of this method is to look for rating performance (priority) on each alternative on each attribute (Lita Asyriati Latif Mohamad Jamil, HI Abbas Said, 2018: 21-22).

The completion algorithm Simple Additive weighting method (SAW) are:

1) Define in advance the criteria that will be made as a benchmark for problem resolution.

2) Normalizing each alternative on each attribute value by calculating the value of rating performance.

3) Calculating the value of the preference weights on each alternative.

4) Doing coupling.

The formula used in the Simple Additive weighting method, namely:

a) Normalizing each alternative (to calculate the value performance rating). 


$$
R i j=\begin{aligned}
& \frac{x_{i}}{\max 1} \\
& \frac{\min x}{x_{i j}}
\end{aligned}
$$

a) Calculating the value of the preference weights on each alternative:

$$
V_{i}=W_{j=1} R_{i j}
$$

Information :

$$
\begin{array}{ll}
V i & =\text { Criteria ranking for each alternative } \\
w j & =\text { The weight of each criteria } \\
R i j & =\text { Values normalized performance rating }
\end{array}
$$

\section{Research methods}

\subsection{Algorithm Implementation Methods SAW best selection of employees at PT. Intiberkah Sinar Sejahtera}

Implementation of algorithms with SAW method in selecting the best employees are the logical steps needed to solve the problem and preparation of programAlgoritma used to analyze and explain the sequence and relationship between activities that will be pursued. The application of this algorithm is very important in designing a program to solve a problem to achieve a goal in the selection algorithm implementation metodeSimple karyawanterbaikdengan Weightin Additive (SAW).With predefined criteria, namely:

1) Ethics

2) Discipline

3) Skil (Expertise in Work)

4) Teamwork

\subsection{System planning}

In this study, there are several steps in designing a system include: shape / appearance of design is made in accordance with the needs of the study area.

\subsection{Implementation}

Are exercising their implementation or application of which will be based on the design of which has been compiled. Implementation should be done with a design that has been made so that the results achieved as expected.

\subsection{Conclusions and suggestions}

The conclusion is the end result of the execution and implementation of decision support systems using this SAW, and advice is a positive form of additional content or in the completion of this research.

\section{Analysis}

\subsection{Problem analysis}

Tearbaik employees in the electoral process is not an easy thing. And decisions are still taken manually and there is no system that helps companies in the selection of the best employees in tepat.Untuk it needed a system in selecting the best employees meentukan use of decision support systems with Simple Additive weighting method (SAW) that can later be used to help in decision-making.

\subsection{Data analysis}

There are also data obtained from the research study are as follows:

a) Data Criteria

1) Ethics

2) Discipline

3) Skil (Expertise in Work)

4) Teamwork

b) Alternative Data
1) Hangga Setiawan
2) ferie Sahputra
3) Bintang Wahyu Utama
4) T. Om Akbar 


\section{5) Dendi Sumanta}

\subsection{Simple Method of Analysis Addetive Weighting (SAW)}

Step - step in Addetive Simple Method Weighting (SAW) is as follows:

Step 1: Determine criteria - the criteria that will be referred to as decision-making criteria Nor ditentuan as follows:
1) Ethics (K1)
2) Discipline (K2)
3) Skil (Expertise in Work) (K3)
4) Cooperation team $(\mathrm{K} 4)$

Step 2: Determine the normalization

$$
\begin{array}{lr}
\frac{x_{i j}}{\max \left(x_{i j}\right)} & \text { If } j \text { is an attribute benefit } \\
\frac{\min x_{i j}}{x_{i j}} & \text { If } j \text { is an attribute (cost) Xij }
\end{array}
$$

$=$
1) Hangga Setiawan (A1)
2) Feri Sahputra (A2)
3) Bintang Wahyu Utama (A3)
4) T. Om Akbar (A4)
5) Dendi Sumanta (A5)

Step 3: Perform rangking

Table 1.

Best Logistick Employee Selection Criteria

\begin{tabular}{cllc}
\hline No. & Criteria and Sub Criteria & \multicolumn{1}{c}{ Information } & Score \\
\hline \multirow{3}{*}{1} & Ethics & Become a rolemodel. & 100 \\
& Become a rolemodel. & .Very good & 90 \\
& Very good & Well & 80 \\
& Well & need Fixing & 60 \\
& need Fixing & & \\
& Discipline & very Discipline & 90 \\
2 & very Discipline & quite Discipline & 70 \\
& quite Discipline & Lack of Discipline & 50 \\
& Lack of Discipline & & \\
& Skil (Expertise in Work) & Very good & 100 \\
& Very good & Well & 80 \\
& Well & Pretty good & 60 \\
& Pretty good & Not good & 40 \\
& Not good & & \\
& Teamwork & Very compact & 80 \\
& Very compact & compact & 70 \\
4 & compact & Compact enough & 60 \\
& Compact enough & Less Compact & 50 \\
\hline
\end{tabular}

Table 2

Alternative ratting On Any Criteria

\begin{tabular}{|c|c|c|c|c|c|c|}
\hline \multirow{2}{*}{ Criteria } & \multirow{2}{*}{ Symbol } & \multicolumn{5}{|c|}{ Data PenentuanKaryawan Best Logistick } \\
\cline { 3 - 7 } & Eangga & $\begin{array}{c}\text { Feri } \\
\text { Setiawan }\end{array}$ & $\begin{array}{c}\text { Bintang Wahyu } \\
\text { Utama }\end{array}$ & $\begin{array}{c}\text { T, Om } \\
\text { Akbar }\end{array}$ & Dedi Sumanta \\
\hline Ethics & K1 & $\begin{array}{c}\text { Become a } \\
\text { rolemodel. }\end{array}$ & Very good. & Need Fixing. & Well. & Well. \\
\hline
\end{tabular}


Table 3.

Alternative ratting On Any Criteria

\begin{tabular}{|c|c|c|c|c|c|c|}
\hline \multirow[b]{2}{*}{ Criteria } & \multirow[b]{2}{*}{ Symbol } & \multicolumn{5}{|c|}{ Data PenentuanKaryawan Best Logistick } \\
\hline & & $\begin{array}{c}\text { Hangga } \\
\text { Setiawan }\end{array}$ & Feri Sahputra & Bintang Wahyu Utama & $\begin{array}{l}\text { T, Om } \\
\text { Akbar }\end{array}$ & Dedi Sumanta \\
\hline Discipline & K2 & $\begin{array}{l}\text { Discipline } \\
\text { enough. }\end{array}$ & Very Discipline. & Less Discipline. & $\begin{array}{c}\text { Very } \\
\text { Discipline. }\end{array}$ & Less Discipline. \\
\hline $\begin{array}{l}\text { Skil (Expertise } \\
\text { in Work) }\end{array}$ & $\mathbf{K 3}$ & Very good. & Well. & Pretty good. & Not good. & Pretty good. \\
\hline $\begin{array}{l}\text { Skil (Expertise } \\
\text { in Work) }\end{array}$ & K4 & Very compact. & Very compact. & Less Compact. & Compact. & Compact enough. \\
\hline
\end{tabular}

Table 4

Match rating

\begin{tabular}{lcccc}
\hline \multirow{2}{*}{ Employee name } & \multicolumn{4}{c}{ Match Rating Criteria } \\
\cline { 2 - 5 } & K1 & K2 & K3 & K4 \\
\hline Hangga Setiawan & 100 & 70 & 100 & 80 \\
Feri Sahputra & 90 & 90 & 80 & 80 \\
Bintang Wahyu Utama & 60 & 50 & 60 & 50 \\
T. Om Akbar & 80 & 90 & 40 & 70 \\
Dendi Sumanta & 80 & 50 & 60 & 60 \\
\hline
\end{tabular}

1. Normalized matrix by calculating the normalized performance values by using the formula (if $\mathrm{j}$ is an attribute benefit):

$$
\begin{aligned}
& \frac{x_{i j}}{\max \left(x_{i j}\right)} \\
& r_{i j}= \\
& \frac{\min x_{i j}}{x_{i j}} \\
& \mathrm{r} 11=\frac{100}{\operatorname{Max}\{100 ; 90 ; 60 ; 80 ; 80\}}=\frac{100}{100} 1 \\
& \mathrm{R} 21=\frac{90}{\operatorname{Max}\{; 100.90 ; 60 ; 80 ; 80\}}=\frac{90}{100} \quad 0.9 \\
& \mathrm{R} 31=\frac{60}{\operatorname{Max}\{100 ; 90 ; 60 ; 80 ; 80\}}=\frac{60}{100} \quad 0.6 \\
& \mathrm{R} 41=\frac{80}{\operatorname{Max}\{100 ; 90 ; 60 ; 80 ; 80\}}=\frac{80}{100} 0.8 \\
& \mathrm{R} 51=\frac{80}{\operatorname{Max}\{100 ; 90 ; 60 ; 80 ; 80\}}=\frac{80}{100} \quad 0.8
\end{aligned}
$$

Normalization for K2

$$
\begin{aligned}
& \mathrm{r} 12=\frac{70}{\operatorname{Max}\{70 ; 90 ; 50 ; 90 ; 50\}}=\frac{70}{90} \\
& \mathrm{R} 22=\frac{90}{90} \\
& \mathrm{R} 32=\frac{50}{\operatorname{Max}\{70 ; 90 ; 50 ; 90 ; 50\}}=\frac{50}{90} \\
& \mathrm{R} 42=\frac{90}{90}
\end{aligned}
$$




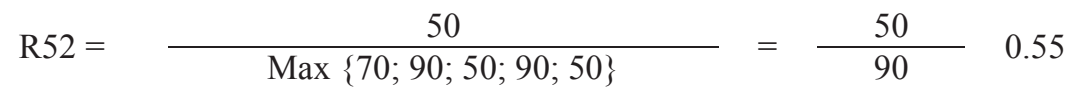

Normalization for K3

$$
\begin{aligned}
& \mathrm{r} 13=\frac{100}{\operatorname{Max}\{100 ; 80 ; 60 ; 40 ; 60\}}=\frac{100}{100} 1 \\
& \mathrm{r} 23=\frac{80}{\operatorname{Max}\{100 ; 80 ; 60 ; 40 ; 60\}}=\frac{80}{100} 0.8 \\
& \mathrm{R} 33=\frac{60}{\operatorname{Max}\{100 ; 80 ; 60 ; 40 ; 60\}}=\frac{60}{100} \quad 0.6 \\
& \mathrm{R} 43=\frac{40}{\operatorname{Max}\{100 ; 80 ; 60 ; 40 ; 60\}}=\frac{40}{100} \quad 0.4 \\
& \mathrm{R} 53=\frac{50}{\operatorname{Max}\{100 ; 80 ; 60 ; 40 ; 60\}}=\frac{60}{100} 0.6
\end{aligned}
$$

Normalization for K4

$$
\begin{aligned}
& \mathrm{R} 14=\frac{80}{\operatorname{Max}\{80 ; 80 ; 50 ; 70 ; 60\}}=\frac{80}{80} \quad 1 \\
& \mathrm{R} 24=\frac{80}{\operatorname{Max}\{80 ; 80 ; 50 ; 70 ; 60\}}=\frac{80}{80} \quad 1 \\
& \mathrm{R} 34=\frac{50}{\operatorname{Max}\{80 ; 80 ; 50 ; 70 ; 60\}}=\frac{50}{80} \quad 0.62 \\
& \mathrm{R} 44=\frac{70}{\operatorname{Max}\{80 ; 80 ; 50 ; 70 ; 60\}}=\frac{70}{80} 0.88 \\
& \mathrm{R} 54=\frac{60}{\operatorname{Max}\{80 ; 80 ; 60 ; 70 ; 60\}}=\frac{60}{80} \quad 0.75
\end{aligned}
$$

From calculations made above, it gets the results of any existing calculation, the results of the above calculation is inserted into the matrix $\mathrm{R}$, Therefore its results are:

$$
\mathrm{R}=\left(\begin{array}{cccc}
1 & 0.78 & 1 & 1 \\
0.9 & 1 & 0.8 & 1 \\
0.6 & 0.55 & 0.6 & 0.62 \\
0.8 & 1 & 0.4 & 0.88 \\
0.8 & 0.55 & 0.6 & 0.75
\end{array}\right)
$$

The next step is to calculate the ranking for each alternative by the formula

$$
\begin{array}{ll}
V i^{=} & =1 \mathrm{Wj} \text { Rij } \\
& j \quad \text { Wherein the weight to attribute }(0.25 \%, 0.25 \%, 0.30 \% \text { to } 0.20 \%) \\
& =(0.25 \% \times 1)+(0.25 \% \times 0.78)+(0.30 \% \times 1)+(0.20 \% \times 1)=0.944 \\
\mathrm{~V} 1 \quad & =(0.25 \% \times 0.9)+(0.25 \% \times 1)+(0.30 \% \times 0.8)+(0.20 \% \times 1)=0.915
\end{array}
$$




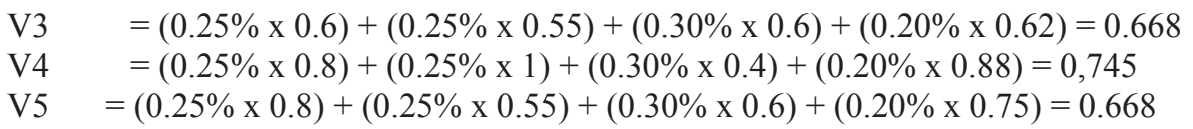

Table 5.

Best Employee Selection Calculation Results

\begin{tabular}{cclcc}
\hline No. & Alternative & \multicolumn{1}{c}{ Name } & Score & Rank \\
\hline 1. & A1 & Hangga Setiawan & $\mathbf{0 . 9 4 5}$ & 1 \\
2. & A2 & Feri Sahputra & $\mathbf{0 . 9 1 5}$ & 2 \\
3. & A3 & Bintang Wahyu Utama & $\mathbf{0 . 6 6 8}$ & 4 \\
4. & A 4 & T. Om Akbar & $\mathbf{0 , 7 4 5}$ & 3 \\
5. & A5 & Dendi Sumanta & $\mathbf{0 . 6 6 8}$ & 5 \\
\hline
\end{tabular}

Conclusions from the above calculation can be seen from Table 4.4 that the candidate who was selected as the best logistic karaywan namely the alternative A1 with Hangga name Setiawan with the result value of 0.945.

\section{Conclusion}

Based on test results, the implementation of the system and conducting interviews, the conclusion of a thesis entitled Decision Support System for the selection of the best employees at PT. Intiberkah Sinar Sejahtera Using Simple Additive weighting method (SAW) is as follows:

a) Decision Support System Selection of Best Employee Simple Method Using Weighting In. The Prosperous Intiberkah rays.

b) Decision Support System using Simple Additive weighting method (SAW) can be applied to help make decisions that resulted in the selection of the best employees for the top priority in an election of the employee.

c) Decision Support System that the company can assist and facilitate the company in taking a decision in the selection of the best employees.

\section{Reference}

[ 1 ]. Dicky Nofriansyah, 2014. Konsep Data Mining Sistem Pendukung Keputusan. Yogyakarta: Deepublish.

[2 ]. Erick Kurniawan, 2010. Visual Basic 2010. Yogkarta: Andi.

[ 3 ]. Haer Talib, 2011. Panduan Lengkap Microsoft Accsess 2010. Jakarta: PT Gramedia.

[4 ]. https://pengertiandefinisi.com, Diakses Tanggal 16 Maret 2019, Jam 21:30WIB

[ 5 ]. Kusrini, 2017. Konsep Dan Aplikasi Sistem Pendukung Keputusan. Yogyakarta: Andi.

[ 6 ]. Rosa A. S, M. Shalahuddin, 2013. Rekayasa Perangkat Lunak. Bandung: Informatika Bandung

[ 7 ]. Lita Asyiati Latif, Mohamad Jamil, Said HI Abbas, 2018. Sistem Pendukung Keputusan Teoori Dan Implementasi, Yogyakarta: Grup Penerbitan CV Budi Utama 